\section{Brexit and the European Shape of Things to Come}

\section{fiona Hunter and Hans de Wit}

Fiona Hunter is associate director, Center for Higher Education Internationalization (CHEI), Università Cattolica del Sacro Cuore, Milan, Italy. E-mail: fionajanehunter@gmail.com. Hans de Wit is director of the Center for International Higher Education at Boston College, US. E-mail:dewit@bc.edu.

$\mathrm{B}$ rexit has happened and UK universities, along with the world of European higher education, are still reeling from a state of shock and disbelief. Academic communities-both staff and students-were fervent supporters of Remain, with their cities also coming out strongly in favor of staying, many well over 70 percent. A key question raised is whether the British exit from the European Union (EU) will also lead to a brain exit from the United Kingdom. Currently, around 5 percent of students in the United Kingdom are from the EU; and collectively they make up the largest international student group, not only bringing diversity to the universities but also generating around $£ 3.7$ billion in income for the UK economy. However, uncertainties around visa requirements and fee levels may lead to a fall in EU applications. Fifteen percent of the UK academic workforce is composed of EU citizens, who now seek reassurance of their positions and prospects. Worrisome reports of incidents of racism on the rise, even in the favorable Remain environments of UK universities, may discourage many from an academic career in the United Kingdom. Given the strong anti-immigrant tone of the Leave supporters, it is likely that academics and students from non-EU countries will become more sceptical about a future in the United Kingdom. This was an ugly campaign, and while the Leave voters did not have higher education in mind when crossing the box on their ballot sheet, the consequences are, and will be, far-reaching for universities, both in the United Kingdom and elsewhere in Europe.

At this moment of flux, all universities can do is seek to minimise disruption by offering reassurance to students and staff, albeit in the short term, around the rights of study and work, but there are many unanswered questions. Concern about research funding runs high, given that UK universities perform disproportionately well in EU programs, and some UK universities are practically reliant on EU research money. The future of access to Erasmus+ is equally uncertain. Perhaps a solution will be found along the Swiss and Norwegian models of participation, paid out of own national resources, but for the moment nothing is certain, also given the state of the UK economy in comparison to the other two countries.

These concerns link to the bigger issues of academic exchange, collaboration, and sharing; of the free movement of talent; and of participation in international networks. A European Higher Education Area without the United Kingdom changes the game for everyone.

\section{How Did We Get Here?}

This outcome would have appeared unthinkable at the beginning of the century, when Europe seemed to be emerging as a stronger and more integrated reality. The European Union had expanded from I5 to the current 28 countries, the euro had been adopted by I9 as a single currency, and the Schengen area had opened borders in $20 \mathrm{EU}$ and six non-EU countries (although the United Kingdom opted out of both.) As the European project made headway, strong internal and external forces started to weaken its foundations. At the global level, the attack on the Twin Towers in New York in 200I generated instability and fear of terrorism, and a more united Europe was perceived by some as a solution, but by others as problematic. Dutch and French voters rejected the European Constitution in 2005, and the economic crisis that began in 2008 generated new tensions and fears. With Europe in the grips of an economic and political crisis, and a refugee emergency unfolding within its borders on an unprecedented scale, the integration process began to fall apart. The issues are now bigger, the climate more tense. The spirit of cooperation has diminished and lack of confidence in Europe has grown, as its institutions have not been able to present credible solutions to the problems faced. Anti-EU sentiment is spreading among the member states, with Brexit as its most dramatic outcome so far.

\section{Brexit and the European Higher Education Area}

The emergence of the European Higher Education Area in the first decade of the century told a different story. Building on the successful experience of Erasmus cooperation, the Bologna Process rapidly gained momentum from four countries in 1999 to 48 countries, 5,600 universities, and 3I million students by 2010 . It focused initially on putting the European house in order through greater commonality in degree structures, credit systems, and quality assurance, but it quickly acquired an external dimension. Convergence of structures and tools was aimed not only at increasing cooperation within Europe, but also at making the continent a more competitive and attractive destination to the rest of the world. This was the period in which European universities began to feel the winds of change, as globalization and the emergence of the knowledge economy required them to develop a more competitive approach, engage in the glob- 
al search for talent, and position themselves beyond their own borders. The Bologna Process offered a framework for shared solutions to shared problems.

While it was hailed as a landmark reform, achieving in only ro years what many national governments had failed to achieve in several decades, the Bologna Process did not evolve along equal paths in the different countries and institutions, and there was significant variation in the pace of change and degree of success in implementation of the action lines. These trends were magnified by the even faster pace of globalization that was creating previously unknown levels of instability and volatility in the economic and political environments of the different EU member states, even though the universities themselves were firm believers inand strong benefiters of-European cooperation.

\section{A key question raised is whether the British exit from the European Union (EU) will also lead to a brain exit from the United Kingdom.}

\section{How Do We Move Forward?}

There is a clear message in Brexit that no matter how international or European universities seek or claim to be, they operate in a national context that will define and, at times, constrain their mission, scope, and activities. This political outcome has the potential to impact negatively on internationalization for the universities, but, at the same time, it raises awareness of the importance in going beyond the rhetoric and purposefully reconnecting internationalization to academic values.

Greater intentionality and integration of internationalization into institutional mission and sense of purpose can enable universities to demonstrate the value and impact of an international community of students and scholars, firstly to themselves, and secondly to the government in the upcoming negotiations. British universities are currently issuing statements around the importance of diversity and how vital it is to their success, but they will need to articulate clearly what it means to have international research collaborations and an international classroom and campus, and how that benefits all members of the university.

They will need to find a way to express internationalization in other terms than for the purposes of prestige and income generation, and demonstrate the importance of a genuinely inclusive approach, as expressed in the statements they are currently making. UK universities are fine examples of institutions that thrive on European cooperation, and are more robust and more able to fulfill their mis- sions as a result of it. The road ahead is an arduous one, but a European Higher Education Area without the United Kingdom would be everybody's loss.

\section{European Universities in the Aftermath of the Economic \\ Crisis}

\section{Jo RITZEN}

Jo Ritzen is professor of international economics of science, technology, and higher education, Maastricht University, Maastricht, the Netherlands.E-mail:j.ritzen@maastrichtuniversity.nl.

A fter a seven-year period, the economic crisis seemed to be over in 2015: economic growth was picking up again in most European Union (EU) countries. During the crisis, economic growth fell, fewer taxes were collected, banks were rescued with public money, government debt levels rose and (youth) unemployment increased. Governments cut budgets in order to satisfy the "Maastricht criteria" of budget deficits and of the government debt-to-GDP (Gross Domestic Product) ratio. This has impacted universities, both through the reduction of direct per-student expenditures and (much less) through the reduction of student aid (loans and grants). Except in the United Kingdom, EU governments barely allowed universities to compensate for the loss of public funding of direct costs through increased tuition fees, although several countries-such as Denmark, the Netherlands, and Swedenintroduced full cost tuition fees for international students outside of the EU.

The financial and economic crisis hit Europe harder than the United States in terms of bailout costs of banks and decline in GDP. This was felt by universities and students alike. More than half of the 22 European countries and regions for which the European University Association collected data, cut government expenditures for university education (including student aid) during the crisis, with the greatest cuts in Greece and Hungary (more than 40 percent). Universities located in the group of countries that had to seek refuge under the umbrella of the European Emergency Fund (Cyprus, Greece, Ireland, Portugal, and Spain) were hard hit in terms of funding direct costs, student aid, and research.

\section{Europe's Competiveness Reduced}

In 2000, the EU launched the Lisbon Strategy, aimed at 